| Research Article / Araştırma Makalesi |

\title{
Investigation of Multiple Intelligence Practises in Social Studies Courses in Context of Textbooks and Teachers' Opinions
}

\section{Sosyal bilgiler Dersi Çoklu Zekâ Uygulamalarının Ders Kitapları ve Öğretmen Görüşleri Bağlamında İncelenmesi ${ }^{1}$}

\section{Nurcan Şener², M. Cihangir Doğan ${ }^{3}$}

\section{Keywords}

1. social studies

2. multiple intelligence theory

3. multiple intelligence applications

\section{Anahtar Kelimeler}

1. sosyal bilgiler

2. çoklu zekâ kuramı

3. çoklu zekâ

uygulamaları

\section{Received /Başvuru}

Tarihi

19.06.2020

Accepted / Kabul Tarihi 26.11.2020

\begin{abstract}
Purpose: The present study was designed to examine multiple intelligence applications in the fourth and sixth-grade social studies learning environments. The research was conducted through case study design, one of the qualitative research patterns. In addition, a face-to-face interview was carried out with eight classroom teachers in fourth grade and social studies teachers in sixth grade at a public and private school in the European side of istanbul.

Design/Methodology/Approach: The data were collected by document analysis and interview techniques and analyzed with content analysis technique.

Findings: According to the results of document analysis, the activities included in social studies textbooks were respectively logical, verbal, and visual activities in terms of intensity. The teachers mostly stated that it gives students the chance of expressing themselves' concerning the message proposed by the theory and emphasized that 'it makes students familiar with different methods and techniques', 'it ensures student-centered learning' and 'it includes students in the lessons more.' The teachers who regarded social studies textbooks as inadequate in terms of multiple intelligence practices mostly stated that 'they have to use the supportive book' and 'the books consist of simple activities inappropriate for students' age'. The majority of teachers who expressed concerns on the requirements for more successful multiple intelligence applications suggested that 'education programs and seminars concerning the theoretical and practical parts of the theory must be arranged' and 'activities with the involvement of students must be organized and learning through experience must be promoted.'

Highlights: In the light of the findings of the study, it is recommended that textbooks must be reviewed in terms of the Theory of Multiple Intelligence, teachers must be encouraged to participate in applied trainings, and the parents must
\end{abstract} be included in these applied trainings, thereby ensuring continuous and permanent learning.

Öz

Çalışmanın Amacı: Bu araştırmanın amacı, "4 ve 6. sınıf sosyal bilgiler dersi öğrenme ortamlarında çoklu zekâ uygulamalarının incelenmesidir. Araştırma, nitel araştırma modeli kapsamında durum çalışması yöntemi ile gerçekleştirilmiştir Talim Terbiye Kurulu tarafından onaylanmış ilkokul 4. sınıf ve ortaokul 6. sınıf sosyal bilgiler kitapları içinde dört ayrı ders kitabı incelenmiştir. Ayrıca, İstanbul ili Avrupa Yakası'nda bulunan bir özel ve bir devlet okulunda görev yapan 4. sınıf, sınıf öğretmenleri ve 6.sınıf, sosyal bilgiler öğretmenlerinden oluşan toplam sekiz öğretmen ile yüz yüze görüşme yapılmıştır.

Materyal ve Yöntem: Veriler doküman incelemesi ve görüşme teknikleriyle toplanmış, içerik analizi tekniğiyle çözümlenmiştir.

Bulgular: Doküman incelemesinden elde edilen sonuçlara göre; sosyal bilgiler ders kitaplarında yer alan etkinliklerin içinde yoğunluğuna göre; mantıksal, sözel ve görsel zekâ etkinlikleri yer almaktadır. Öğretmenler, kuramın kendilerine verdiği mesaj ile ilgili en çok; “öğrenciye kendini ifade etme özgürlüğü tanıdığını” belirtmiş, "değişik yöntem ve teknikleri öğrencinin önüne getirdiği" ve "öğrenci merkezli öğrenmeyi sağladığı", "öğrenciyi derse daha fazla dâhil ettiğini" vurgulamışlardır. Sosyal bilgiler ders kitaplarının çoklu zekâ etkinlikleri açısından yeterli olması konusunda yetersiz görüş bildiren öğretmenlerin en çok; "yardımcı ders kitabı kullanma zorunda kaldıkları", "yaşlarına uygun olmayan, basit etkinliklerin mevcut olduğu" görüşleri ön plana çıkmıştır. Çoklu zekâ uygulamalarının daha başarılı olabilmesi için yapılabileceklere yönelik görüş bildiren öğretmenlerin çoğu; "kuramın teorik kısmıyla uygulamasına yönelik eğitim ve seminerler düzenlenmesi", "öğrencilerin de dâhil oldukları etkinlikler düzenlenmesi, yaşayarak öğrenmelerinin sağlanması gerektiği" görüşlerini bildirmişlerdir.

Önemli Vurgular: Araştırmadan elde edilen bulgular çerçevesinde; ders kitaplarının Çoklu Zekâ Kuramı açısından yeniden ele alınması, öğretmenlerin kuram ile ilgili uygulamalı eğitimlere katılımlarının teşvik edilmesi, bu eğitimlere velilerin de dâhil edilerek öğrenmelerin sürekliliği ve kalıcılığının sağlanması önerilmektedir.

\footnotetext{
1 This paper is adapted from the dissertation study carried out in Marmara University Institute of Educational Sciences Classroom Teaching Doctoral Program entitled 'Investigating Multiple Intelligence Applications in Learning Environments of the Course of Social Studies'.

2 Corresponding Author, Marmara University, Atatürk Faculty of Education, Department of Elementary Education, İstanbul, TURKEY; https://orcid.org/00000002-1987-1717

${ }^{3}$ Marmara University, Atatürk Faculty of Education, Department of Elementary Education, İstanbul, TURKEY; https://orcid.org/0000-0003-1473-7866
}

Alıntı/Citation: Şener, N., \& Doğan, M. C. (2021). Sosyal bilgiler dersi çoklu zekâ uygulamalarının ders kitapları ve öğretmen görüşleri bağlamında incelenmesi, , 29(3), 643-653. doi: 10.24106/kefdergi.754945. 


\section{INTRODUCTION}

In today's world, rapid developments and changes in every aspect bring about fundamental changes in national education systems (Çăglayan and Kıratlı, 2017). On the basis of those developments and changes is the need to raise healthy and successful individuals by all odds and lead them in accordance with their abilities and interests. In this regard, it is worth noting that individuals' learning process is affected by their differences and characteristics (Kuzgun and Deryakulu, 2017). Therefore, individual differences among students should be taken into consideration by teachers while arranging teaching-learning environments. Therefore, the teaching-learning environment should be shaped based on the fact that each student has different learning styles and intelligence types (Inan and Erkuş, 2016). In recent years, as a curricular innovation in schools, the traditional approach adopting behaviorism has been intended to be replaced by constructivism and multiple intelligence practices. Accordingly, teachers' roles have been re-defined, and different responsibilities and abilities have come to the fore; in addition, it has become a must to appeal to multiple intelligence modalities in educational practices and carry out teaching processes addressing different intelligence types. In the Theory of Multiple Intelligence, educational processes planned with appropriate activities enable students to receive an education that meets their own individual differences. This process is subjectified based on individuals' prior experiences and learning (Kabapınar, 2012). Gardner (2019) introduced eight different types of intelligences and noted that there may be other candidate intelligences over time. The intelligences modalities described by him include verbal/linguistic intelligence, logical/mathematical intelligence, visual/spatial intelligence, bodily/kinaesthetic intelligence, musical/rhythmic intelligence, social/interpersonal intelligence, intrapersonal intelligence, and naturalistic intelligence. Gardner kept on developing his efforts in this field, and he added another type, existential intelligence, as the ninth type in the list of multiple intelligences (Fleetham, 2014). Below, the intelligence types as conceptualized in the Theory of Multiple Intelligence are described in detail, with the aim of clarifying the research:

Verbal/ Linguistic Intelligence: Also known as reading, writing, and speaking intelligence, it is, unawarely, the most prevalent intelligence type. Furthermore, it is the most remarkable intelligence type amongst individuals. Gardner (1993) stressed that language was a preeminent example of human intelligence and had indispensable importance in the process of socialization. Humans are able to analyze memories, handle problems properly and construct their future thanks to their thinking skills with words (Campbell, Campbell, and Dickinson, 1996; as cited in Bümen, 2005).

Logical/Mathematical Intelligence: This intelligence type is misinterpreted and not completely understood. The idea that the individuals possessing this type of intelligence are considered to be only good at mathematical operations does not reflect the truth. On the contrary, individuals with this intelligent type have the ability to consider the problem from various perspectives. They are able to inquire through deductive and inductive approaches and propose solutions by taking different cause and effect relationships into consideration (Bellenka, 1997).

Visual/Spatial Intelligence: Visual intelligence is completely different from looking at something. Individuals with this intelligence type have a good sense of reviewing and interpreting visual images. Temiz (2007, p. 25) claimed that visual/spatial intelligence is beyond drawing a picture; instead, it is associated with reading a map, finding an address, remembering where an object is, making cognitive imaginations, and printing it on a paper.

Bodily/Kinaesthetic Intelligence: Individuals with bodily/kinaesthetic intelligence are able to employ their bodies in different activities via strong communication between their body movements and brains. Also known as sensorimotor intelligence, it refers to the potential of using the whole body or parts of the body by integrating the mind and body with great harmony and willpower (Gardner, 1993).

Musical/Rhythmic Intelligence: Musical intelligence is related to the identification of tones, melodies, sounds, and rhythm. Individuals with this intelligence type learn best through rhythm, melody, and music (Tuğrul and Duran, 2003). Musical intelligence is a unique type of intelligence that is easily applicable to all learning situations. The individuals who excel in this intelligence type have a strong ability to recognize such music-relevant factors as rhythm, acoustics, melody, cadence, and other components of music.

Social/Interpersonal Intelligence: An individual with a high level of interpersonal ability would likely possess both an awareness of people's characteristics and also an understanding of them. Individuals who are high in social intelligence are capable of cooperating with group members in a group, working in harmony, and communicating verbally or non-verbally with others (Saban, 2005). The high level of social intelligence is correlated more strongly with an individual's self-confidence and qualified communication with others.

Intrapersonal Intelligence: This intelligence type is described as 'self-knowledge, a clear concept of oneself and the ability to assume responsibility for life and learning' (Doğan, Alkış, 2007, p. 330). From Gardner's description, intrapersonal intelligence is the 'key intelligence in life, and it represents the awareness of one's own self-knowledge and his/her ability to take responsibility for his/her own life and learning' (Demirel, 2000, p. 151). Thus, an individual having this intelligence type is aware of his/her own self and becomes self-sufficient (Erman, 2003).

Naturalistic Intelligence: This intelligence type is directly related to the individual's capacity to perceive, appreciate, and understand the natural world (Doğan and Alkıs, 2007; Bellenka, 1997). She/he is sensitive to the problems regarding both living and non-living objects and lifecycle. She/he seeks solutions for environmental health. 
Gardner (2019) asserted that each individual has a unique profile of intelligences of varying strengths and highlighted the cultural dimension of intelligence shaped by biology and environment. He also added that inherited intelligence does not have the chance to develop if it is not of paramount importance in society. According to Gardner, the fact that people are different from one another is due to the fact that the combination of intelligence profiles is not the same in each individual. The Theory of Multiple Intelligences, therefore, has been especially powerful in the context of education. The theory suggests that each individual is different from one another and, not surprisingly, talented in different fields. The idea that an individual regarded as successful in a certain field would be successful in other areas as well has been, hereby, outdated. The individuals' talents in different fields are substantially related to their intelligence profiles and dimensions (Demirel, Başbay, and Erdem, 2006). Those changes in education have also led to a change in teachers' roles and responsibilities. A teacher does not adjudge or establish rules; instead, she/he is the one who teaches his/her students how to learn and leads them to handle a problem properly (Kuran, 2005). In this regard, through proper guidance, a student understands that making mistakes while learning is of great importance, should definitely not be regarded as a failure, and, contrary to this, it is a chance to learn. If she/he is not able to solve a problem in a certain way, she/he notices that there is another way to handle it. No experience is the same as another, and the unique wisdom of each experience comes into existence only when experienced holistically (Peterson and Kolb, 2018).

It is quite compelling to nourish the interests of children who are continuously subjected to different stimulants. For this reason, it seems necessary to provide them qualified, permanent, and entertaining learning processes through activities addressing different intelligence domains. In addition, several changes around the world have entailed reconsidering curricula, adopting modern approaches, and altering course books which are the main instruments of in-class learning. Within this period, investigation of course books and teachers' views is highly significant. The originality of the research underlies the fact that no study elaborating on this topic has been encountered when examining prior studies on the course books in Turkey.

The present study is designed to 'examine multiple intelligence applications in the 4th and sixth-grade social studies learning environments.' To this end, answers to the following questions have been sought:

1. To what extent the activities in 4th and sixth-grade social studies course books are appropriate for the Theory of Multiple Intelligences?

2. What are the opinions of 4th and sixth-grade teachers on the use of the Theory of Multiple Intelligences in social studies learning environments?

\section{METHOD}

The research was conducted through case study design, one of the qualitative research patterns. Case study is considered appropriate for this research as 'it is used in such situations as, for instance, analyzing the current fact within the frame of its life or the situations as having more than data and an evidence' (Yin, 1984; as cited in Yıldırım and Şimşek, 2011, 281). A holistic multiple-case study design has been employed in this study. In a holistic multiple-case study design, there is more than one case that may be regarded as holistic by itself, and each case is examined in itself, then they are integrated with one another (Yıldırım and Şimşek, 2011). At the first phase of the study, activities included in 4th and sixth-grade social studies course books were analyzed in detail within the context of multiple intelligences. Then, at the second stage, a face-to-face interview with classroom and social studies teachers were carried out through semi-structured interview form concerning the application of multiple intelligences in educational environments.

\section{Study Group}

The study group was determined by using a criterion sampling strategy, one of the purposeful sampling methods. Criterion sampling involves selecting cases based on some predetermined criteria. Here, the criterion can be formed by the researcher, or a predetermined criterion list can be used (Yıldırım and Şimşek, 2011). Accordingly, four different course books in 4th and 6th grade in the social studies field published by three different publishers approved by the Board of Education and Discipline in 20192020 academic year and eight teachers who were classroom teachers at fourth grade and social studies teachers at sixth grade at a public and private school in the European side of Istanbul were included in the research. Teachers' years of service varied between 5 and 41 years, and three of them were female, five of them were male teachers. Furthermore, the study group was determined based on the 'convenience sampling' model, one of the purposeful sampling methods. This model was chosen due to the fact that the schools and teachers in these schools were easy-accessible and had appropriate physical conditions for the activities.

\section{Data Collection Instruments}

As data collection instruments, 'document analysis' where the activities addressing multiple intelligences in course books in fourth and sixth grade in social studies field approved by the Board of Education and Discipline in 2019-2020 academic year and 'semi-structured interview form' with teachers were used.

Document analysis involved the processes of reviewing related literature and forming a conceptual framework concerning social studies courses and multiple intelligences. Besides, the suggestions of academicians studying in different fields were attempted to be included in the research. The conceptual framework assisted the researcher with developing data collection instruments and obtaining findings. The opinions of three academicians who excel in the field were asked in order to investigate 
to which intelligence domain the activities in course books appeal and to ensure validity. The codes were re-arranged, and the study was carried out.

During the implementation of the semi-structured interview form, expert opinion was asked in order for questions to be clear, intelligible, and in accordance with the purpose of the study. In addition, certain questions regarding what they did concerning multiple intelligences were asked to three classes and three social studies teachers that were not included in the study group and were requested to write a composition. Their responses were analyzed by three academicians through content analysis. Finally, the questions agreed to be included in the interview form were selected.

\section{Data Analysis}

The goal of data analysis is to interpret the responses, observations, and written data and put them into perspective (Merriam, 2018). In the current research, content analysis was employed to analyze the research data. Content analysis is a research tool used to organize and elicit meaning from the data collected and draw realistic conclusions from it. In this regard, the data collected were conceptualized first, then certain arrangements were conducted based on those concepts and themes explaining the data were formed (Yıldırım and Şimşek, 2011). In the present study, the activities in the fourth and sixth grade social studies course books were examined, and, accordingly, the data obtained were coded. The content analysis was investigated again following determining intelligence domains addressed by the activities. The implementations carried out by a researcher were analyzed by another researcher and, then numeric analyses were conducted by calculating intelligence domains specified in the course books. Finally, the data obtained were tabulated and interpreted.

In the process of semi-structured interview form analysis, teachers were requested to read their own responses in order to ensure that there were no statements in the forms except the ones uttered by them. The data obtained were coded and divided into categories. The data were classified under these categories, and the teachers' responses were analyzed in-depth. Similar responses were included in the same categories. The statements in teachers' responses were attached meaning, and themes were identified. The categories obtained were confirmed by another researcher. The frequency values of categories were calculated, tabulated and the data were supported by direct citations. The pseudonyms were used in order to ensure confidentiality. Instead, such codes as T1, T2..., T8 were preferred.

\section{Validity and Reliability}

In the current research, the implementations carried out by a researcher were analyzed by another researcher and, then, intelligence domains specified were calculated, and numeric analyses were conducted. Convergent reliability and consistency were assessed. The consistency was calculated based on the formula described in Miles and Huberman (1994):

Reliability = Number of Agreements/ Number of Agreements + Disagreements

The reliability value for intelligence domains, addressed by the activities in social studies course books, calculated through the formula above was shown in Table 1.

Table 1. Reliability Values for Intelligence Domains Addressed by the Activities

$\begin{array}{lc}\text { Books } & \text { Reliability } \\ \text { Course Book } & 88 \%\end{array}$

According to Table 1, reliability between the codes created by two different researchers was found high. The high level of consistency is regarded as the internal reliability of qualitative analyses.

The responses gathered from the interview form were examined in-depth; moreover, meaningful parts and statements were determined. The classifications of the data obtained from interviews were made based on Miles and Huberman's (1994) formula, and convergent reliability was found as $88 \%$.

\section{FINDINGS}

This section covers the findings related to the results of the analysis on the basis of research goals.

\section{Findings concerning Course Books}

The findings regarding multiple intelligence domains addressed by the activities in social studies course books are presented in Table 2. 
Table 2. The Distributions concerning the Multiple Intelligences Activity Types in Social Studies Course Books

\begin{tabular}{|c|c|c|c|c|c|}
\hline \multirow{2}{*}{$\begin{array}{l}\text { Intelligence } \\
\text { Domains }\end{array}$} & \multicolumn{2}{|l|}{ Course books } & \multirow[b]{2}{*}{ MoNE Sixth Grade } & \multirow[b]{2}{*}{ Altın Sixth Grade } & \multirow[t]{2}{*}{ Total } \\
\hline & MoNE Fourth Grade & Tuna Fourth Grade & & & \\
\hline Logical & 73 & 66 & 85 & 84 & 308 \\
\hline Verbal & 24 & 45 & 40 & 110 & 219 \\
\hline Visual & 37 & 21 & 38 & 31 & 127 \\
\hline Social & 15 & 29 & 22 & 12 & 78 \\
\hline Intrapersonal & 37 & 16 & 5 & 15 & 73 \\
\hline Naturalistic & 4 & 8 & 4 & 19 & 35 \\
\hline Musical & 1 & - & - & - & 1 \\
\hline Kinaesthetic & - & - & - & - & - \\
\hline $\begin{array}{l}\text { Total Number of } \\
\text { Activities }\end{array}$ & 191 & 376 & 194 & 271 & 841 \\
\hline $\begin{array}{l}\text { The Number of } \\
\text { Pages(Net) }\end{array}$ & 134 & 178 & 148 & 134 & 594 \\
\hline Activity/Page Rate & 1.4 & 2.1 & 1.3 & 2 & 1.4 \\
\hline
\end{tabular}

As shown in Table 2, the activities in MoNE fourth grade social studies course books (MoNE, 2005) mostly appealed to the logical intelligence domain $(n=73)$. Similarly, the activities in Tuna $4^{\text {th }}$ grade social studies course books address the logical intelligence domain $(n=66)$. The same situation has been observed in the activities in MoNE sixth grade social studies course books; those activities mostly appealed to the logical intelligence domain $(n=85)$. However, the activities in Altın sixth grade social studies course books addressed the verbal intelligence domain $(n=110)$. Furthermore, in Table 2, the intelligence domains addressed by the activities in course books were determined respectively as follows: logical intelligence $(n=219)$, social intelligence $(n=78)$, intrapersonal intelligence $(n=73)$, naturalist intelligence $(n=35)$, musical intelligence $(n=1)$. No activity appealing to kinaesthetic intelligence was found in the activities.

In addition, as for the rate of the number of activities addressing multiple intelligence domains to the net number of pages in course books, the activity/page rate in MoNE (2005) fourth-grade social studies course book was found as 1.44; in Tuna fourthgrade social studies course book as 2.11; in MoNE (2005) sixth-grade social studies course book as 1.31 and in Altın sixth-grade social studies course book as 2.02. With this regard, the highest number of activities addressing multiple intelligences depending on the number of pages was found in Tuna fourth-grade social studies course book. Besides, a total number of multiple intelligences activities depending on the number of pages was found as 841 , and the number of primary activities/the number of pages of the course books rate was determined as 1.41. Below is an example of the activities in course books:

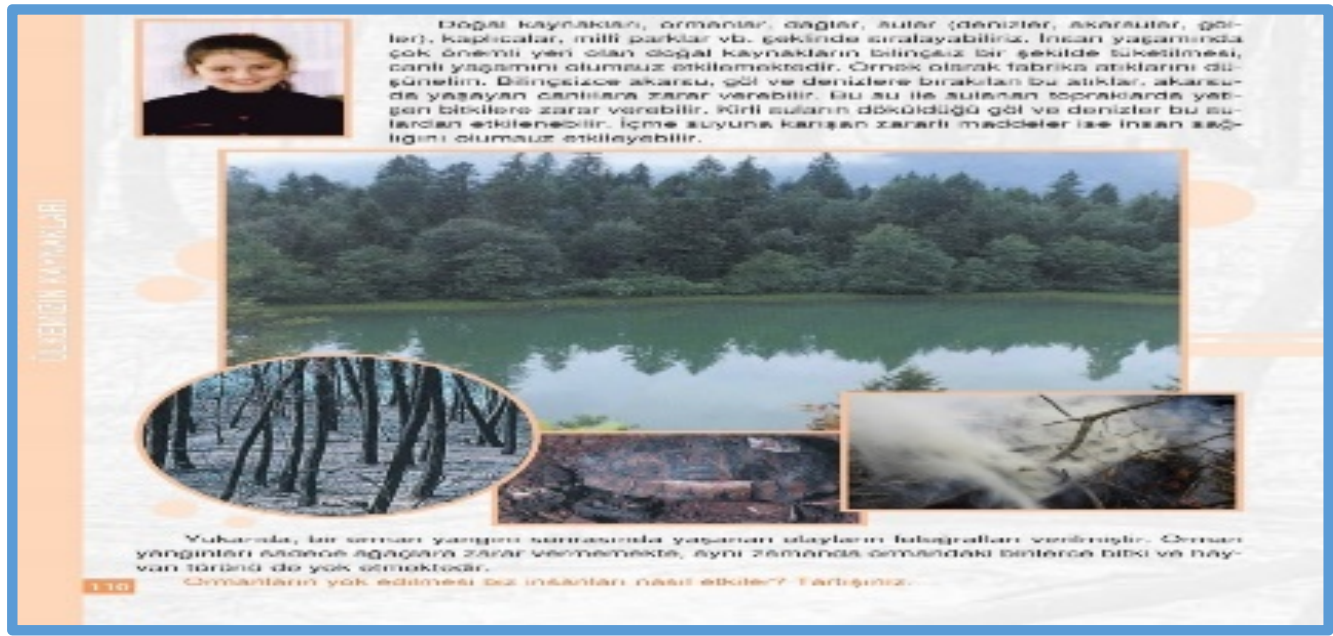

Figure 1. Social Studies Course Book. Altın Publishing, p. 110.

In Figure 1, a text regarding the subject of 'Our Natural Resources not be Scarced' in 'Resources of Our Country' unit was presented to students. The text appeals to verbal and visual intelligence domains. Here, students were asked how people are affected by the destruction of forests, and they were requested to discuss this topic. With this activity, it was addressed to students' naturalistic intelligence in the first place; then, thanks to verbal and visual texts, logical-mathematical intelligence was appealed by requesting drawing conclusions from the text. 


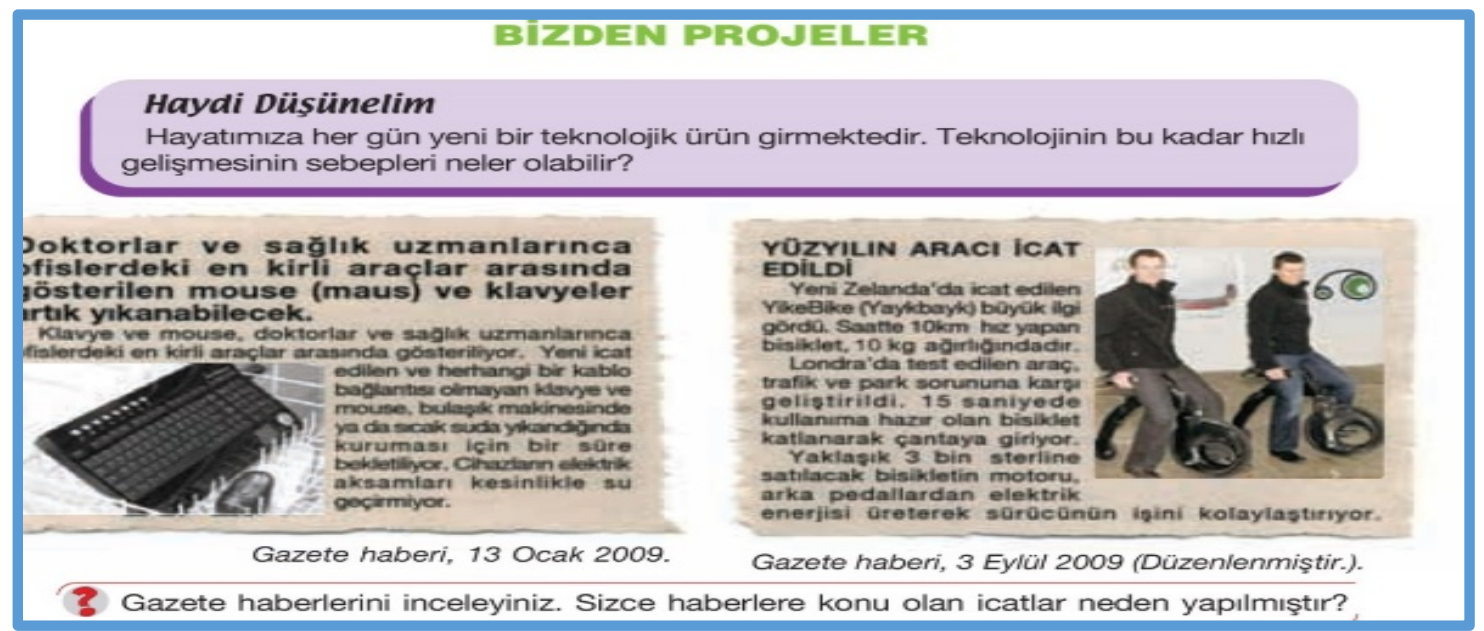

Figure 2. Social Studies fourth-Grade Course Book (Second Book), MoNE, p.118.

In Figure 2, 'Let's Think!' activity and two newspaper reports were included in the preparation part of 'Our Projects' subjects within 'Glad that We Have' unit. In 'Let's Think!' activity, the students were asked 'Each day, a new technological product come into our lives. What are the reasons for this rapid technological advancements?' This question was aimed to address logical intelligence domain. In the second part of the activity, regarding verbal and logical-mathematical intelligence domains, students were requested to investigate newspaper reports and asked, 'Why do you think the inventions mentioned in these newspaper reports were made?'

\section{The Findings concerning the Interviews with Teachers}

This section covers the findings related to the findings gathered from the recordings of interviews with teachers.

\section{Teachers' Views on the Messages Conveyed by the Theory of Multiple Intelligences}

Regarding multiple intelligences theory, teachers stated that 'it allows students to express himself/ herself' ( $n=2)$, 'it provides different methods and techniques to students' $(n=2)$, 'it ensures student-centered learning' ( $n=2)$, 'it prevents learning from being monotonous' $(n=1)$, 'it focuses on students' individual requests' $(n=1)$, 'it ensures effective and permanent learning' ( $n=1)$, 'it focuses on students' interests and requests' ( $n=1)$ and 'it allows novel opinions to merge' $(n=1)$.

The examples concerning teachers' statements on the messages conveyed by multiple intelligences theory are provided below:

T6; "I do not have much information about the Theory of Multiple Intelligence. I am in favor of the fact that students have the right to express their opinions explicitly."

T1; "The Theory of Multiple Intelligences is a new concept for me. However, as far as I am concerned, this is a method I have already attempted to implement. I think that, according to this theory, we should allow our students to express their interest and requests explicitly."

T2; "For me, the Theory of Multiple Intelligences is a way to help different opinion patterns to merge."

\section{Teachers' Views on the Key Elements Paid Attention during the Implementation of Multiple Intelligences}

Regarding the key elements paid attention during the implementation of multiple intelligences, teachers articulated that 'they pay attention to individual characteristics' $(n=3)$, 'they apply different methods and techniques based on students' interests and curiosities' ( $n=2)$, 'they allow their students to express themselves explicitly' $(n=1)$, 'they prepare different activities based on their students interests, talents and requests' $(n=1)$, 'they plan certain activities appealing to visuality' ( $n=1)$, 'they pay attention to implement certain activities addressing five senses' $(n=1)$ and 'they attempt to ensure equality of opportunities' ( $n=1)$.

The examples concerning teachers' statements on the key elements paid attention during the implementation of multiple intelligences are presented below:

T3; "I pay attention to apply certain activities addressing five senses. For example, in the lessons when I use globes, my students can see the localization of our country while being happy by touching the globe, thereby ensuring permanent learning."

T8; "The development of visual, auditory and social intelligence contributes to both student's personal development and academic achievement. Applying different methods depending on students' interests, for example, presentations, the use of globe, films etc. make contributions to students' success."

T1; "Based on students' interests and talents, I allow them to express their emotions, opinions, and ideas without permitting class discipline to be ruined. I arrange a number of activities with an aim to make them express their ideas explicitly in society and be creative and explorer." 
Teachers' Views on the Difficulties Faced during the Implementation of Multiple Intelligences

Table 3 presents the frequencies of social studies teachers' responses concerning the difficulties faced by them during the implementation of multiple intelligences.

Table 3. The Frequencies concerning the Difficulties Faced by Teachers during the Implementation of Multiple Intelligences

\begin{tabular}{lc} 
Views & F \\
Inadequacy of Materials & 3 \\
Intensive Curriculum & 2 \\
The need for teachers' being more active and well-informed & 2 \\
Inadequacy of lesson hours with regard to subjects & 2 \\
Having difficulty in including parents in the process & 1 \\
Having difficulty in ensuring classroom arrangement due to students' being quite active & 1 \\
The students' who do not have the right to speak being offended & 1 \\
The inappropriateness of educational environments for multiple intelligences & 1 \\
Having difficulty in meeting individual interests and needs & 1 \\
The inappropriateness of course books for multiple intelligences & 1 \\
The students' being accustomed to rote learning & 1 \\
Total & 16 \\
\hline
\end{tabular}

According to Table 3, regarding the difficulties faced by classroom teachers and social studies teachers during the implementation of multiple intelligences, they emphasized that 'they are faced with inadequacy of materials' ( $n=3$ ), 'they are faced with an intensive curriculum' $(n=2)$, 'the teacher himself should be more active and well- informed' $(n=2)$, 'they are faced with insufficient lesson hours' $(n=2)$ and 'they have difficulty in including parents in the process' $(n=1)$.

The examples concerning teachers' statements on the difficulties faced during the implementation of multiple intelligences are presented below:

T5; "The biggest difficulty I have ever faced during the implementation process is the inappropriateness of educational environment for this theory and inadequacy of materials."

T; "Inadequacy of materials, insufficient lesson hours, intensive curriculum and our having difficulty in keeping up with this curriculum."

Teachers mostly noted that they were faced with the inadequacy of materials while preparing activities for different intelligence domains and added that the educational environment was inappropriate for multiple intelligence practices. Moreover, teachers highlighted the same points during the negotiations except for interviews.

Teachers' Views on Students' Skills Contributed by Multiple Intelligence Practices

Table 4 covers the data concerning fourth, sixth, and classroom teachers' views on students' skills contributed by multiple intelligence practices in social studies courses.

Table 4. The Frequencies concerning Teachers' Views on Students' Skills Contributed by Multiple Intelligence Practices

\begin{tabular}{ll}
\hline Views & F \\
Ability to express himself/ herself in a more comfortable way & 2 \\
Empowerment of self-confidence & 2 \\
Ability to raise awareness of his/ her own talents and develop self- acquaintance & 2 \\
Being more successful in each step of life & 1 \\
Increase in self-confidence & 1 \\
Being more eager to learning & 1 \\
Enhancement of creativity & 1 \\
Ability to learn to respect his/ her friends/ teachers opinions & 1 \\
Ability to propose different ways to handle a problem & 1 \\
Ability to improve verbal and visual intelligence, memory, and imagination & 1 \\
Better recognition of the environment & 1 \\
Ability to establish cause and effect relationships concerning the environment & 1 \\
Ability to consider subjects from different perspectives & 1 \\
Allowing students to learn by experiences instead of rote learning & 1 \\
Enhancement in visual and auditory intelligence domains & 1 \\
Total & 18
\end{tabular}


As presented in Table 4, regarding students' skills contributed by multiple intelligence practices in social studies courses, teachers stated that 'students are able to express themselves in a more comfortable way' ( $n=2)$, 'students' self- confidence are empowered' $(n=2)$, 'students become aware of their talents and are able to develop self- acquaintance' ( $n=2)$, 'students are more successful in each step of life' ( $n=1)$ and 'students' self-respect is improved' $(n=1)$.

The examples concerning teachers' views on students' skills contributed by multiple intelligence practices in social studies courses are provided below:

T2; "They are able to express themselves in a more comfortable way. Their self-confidence and self-respect improve. They learn to respect their friends and teachers and others' opinions. They are able to propose solutions to handle a problem fearlessly."

T4; "They become aware of their own talents and skills. It contributes better self-recognition."

\section{Techers' Views on Social Studies Course Books' Sufficiency in terms of Multiple Intelligence Activities}

Table 5 presents fourth and sixth- grade teachers' views on social studies course books' sufficiency in terms of multiple intelligence activities. Teachers' responses were classified as 'Sufficient', 'Partially Sufficient' and 'Insufficient'.

\section{Table 5. The Frequencies concerning Teachers' Views on Social Studies Course Books' Sufficiency in terms of Multiple} Intelligence

\begin{tabular}{|c|c|}
\hline Course Book & $f$ \\
\hline Insufficient & 18 \\
\hline Being obliged to use a supportive book & 3 \\
\hline The number of subjects' being excessive in course books & 2 \\
\hline Poor presentation style of the subjects & 1 \\
\hline The subjects' not being far-reaching & 1 \\
\hline Poor integrity among subjects & 1 \\
\hline The subjects should be designed in a better way & 1 \\
\hline The visuals should be more interesting & 1 \\
\hline The designs should be better & 1 \\
\hline The visuals should be more interesting & 1 \\
\hline Insufficient in terms of information and content & 1 \\
\hline The subjects are not contemporary & 1 \\
\hline The environmental factor was not taken into consideration & 1 \\
\hline Insufficient in terms of leading students to investigate and research & 1 \\
\hline Failure to offer information entailed for the exams carried out in the country & 1 \\
\hline Inappropriate for the country's educational facts & 1 \\
\hline Partially Sufficient & 7 \\
\hline Insufficient lesson hours & 2 \\
\hline Insufficiency of dialogue texts & 1 \\
\hline Insufficiency of topics regarding the importance of a certain day & 1 \\
\hline Books' printing quality is quite poor & 1 \\
\hline The subjects in which students can be more active should be included more & 1 \\
\hline Insufficiency of dialogue texts & 1 \\
\hline Sufficient & - \\
\hline Total & 25 \\
\hline
\end{tabular}

According to Table 5, teachers considering social studies course books insufficient in terms of multiple intelligence practices stated that 'they have to use supportive book' $(n=3)$, 'there are too many subjects in course books' $(n=2)$, 'the presentation styles of subjects are poor' $(n=1)$, 'the subjects are not far- reaching' $(n=1)$, 'the integrity among subjects are poor' $(n=1)$ and 'the subjects should be designed in a better way' $(n=1)$. However, the teachers considering the course books partially sufficient noted that 'the lesson duration is insufficient' $(n=2)$, 'the dialogue texts are insufficient' $(n=1)$, 'the subjects are insufficient in terms of the importance of a certain day' $(n=1)$, 'the books' printing quality is poor' $(n=1)$, 'the subjects in which students can be more active should be included more in course books' $(n=1)$ and 'the dialogue texts are insufficient' $(n=1)$. On the contrary, there have been no teachers' views stating that course books are sufficient.

The examples concerning teachers' views on social studies course books' sufficiency in terms of multiple intelligence activities are presented below:

T5; "I think that course books are not appropriate for the current education system in Turkey; in this regard, I find them insufficient." 
T8; "As a Social Studies teacher, I do not think that the presentation styles of subjects are different from the ones published in the past years. There is no integrity among subjects. In addition, the books' printing quality is not good."

T6; "I find course books insufficient in terms of information and content. I think that the subjects should be adapted according to today's world. Moreover, I find the course books quite insufficient in terms of leading students to investigate and research."

\section{RESULTS, DISCUSSION, AND SUGGESTIONS}

The results of the study have shown that the activities in course books mostly appeal to the logical intelligence domain; however, musical or kinaesthetic intelligence domains are either included in course books with a limited level or not included. Since there were certain activities mostly addressing the logical intelligence domain, they allow creative thoughts to merge, and students are led to explain their opinions based on their current information. Nevertheless, the fact that other intelligence domains are not much included in course books- this situation is verified by teachers' views - requires reconsidering those books in terms of the Theory of Multiple Intelligence and to vary and arrange the activities based on different intelligence domains. This is considered significant in order for students to be able to think and explain their thoughts. The fact that different intelligence domains are included at similar levels in course books is important in order for sophisticated, social, and qualified individuals aimed by the course to reveal their intelligence domains. Yeşildere (2003) stated that students would be aware of their skills, recognize themselves, have a higher level of academic achievement and self-confidence on the condition that intelligence domains were integrated with appropriate learning environments.

The majority of teachers interviewed were revealed to have positive and negative views on the Theory of Multiple Intelligence. The 'positive' views are stated as follows: 'it prevents learning environments from being monotonous, students' experiencing success thanks to the activities addressing different intelligence domains, enhancing students' self-confidence and its contribution to academic achievement.' These results are in accordance with the findings of a study by Gülfırat Kıbrız (2016). In the study, it was observed that there was a difference between post-test scores on experiment and control groups, and this difference was in favor of the experiment group in which multiple intelligence practices were conducted. This result indicated that multiple intelligence practices in social studies course had an impact on student achievement.

The 'negative' views on the Theory of Multiple Intelligences are as follows: 'inadequacy of opportunities, difficulties faced in the context of students' exploration of their own talents and problems resulted from teachers.' In today's world, individuals are required to be venturous, to have critical and creative thinking, to search and inquire, to propose alternative solutions for different problems, to be brave to try and eager to learn, to produce knowledge, and to follow technological advancements (Demircioğlu, 2005; Kaytancı and Dombaycı, 2020). In this regard, social studies course, by definition, should possess a more effective learningteaching process, and teachers, as practitioners, should have more qualified competencies. Acat (2005) attempted to determine the utility of the Theory of Multiple Intelligences to plan and arrange learning-teaching situations in Turkey's conditions. A certain number of findings is in line with the results of the current study. The key factor to be paid attention to regarding the implementation process of multiple intelligences is that teachers are entailed to have a broad theoretical framework concerning the theory and implementation methods. In light of the results of the study, teachers need to pay attention to the fact that the contents of activities carried out in the learning process should appeal to students' all intelligence domains, and different methods and techniques should be included in the implementation process. Moreover, teachers should consider students' developmental characteristics and their changes during the learning process and talents.

Among teachers' responses concerning the key elements paid attention to during the implementation of multiple intelligences is the fact that 'they attempt to carry out different methods and techniques considering individual differences and students' different interests and curiosities.' Furthermore, teachers stated that 'students are able to express themselves in a better way, their self-confidence is empowered, they become aware of their abilities and recognize themselves better, and their self-respect is enhanced' through multiple intelligence practices. It is unlikely for a teacher to excel in all intelligence domains; however, it is of importance that she/he explores the resources by which she/he is able to prepare qualified activities concerning different intelligence domains, to make inferences, and to introduce new outcomes (Saban, 2002). The underlying reason why teachers agree on this issue to a great extent may be due to the fact that they are not well-informed about the Theory of Multiple Intelligences, and they do not include multiple intelligence practices in the lessons because of various reasons. This result is in accordance with teachers' responses during interviews.

Teachers' responses regarding the difficulties faced during the implementation of multiple intelligences are as follows: 'inadequacy of materials, intensive curriculum, the need for teachers to be more active and well-informed compared to traditional teaching approach, insufficient lesson hours and difficulties in including parents in the process.' The results of the study are in line with the study conducted by Başbay (2005) whoattempted to find out teachers' opinions on the process in a teaching-learning environment arranged in accordance with the Theory of Multiple Intelligences. Similarly, teachers who had negative views on the process emphasized inadequacy of time, intensive curriculum and exams, and examination anxiety. Likewise, in a study conducted by Yeşilbursa (2006) entitled 'The Views of the Teachers of the Primary Education Second Grade Social on Multiple Intelligence Theory', it was determined that physical conditions of schools were not appropriate for multiple intelligence theory, parents were not much well-informed about the theory, social studies teachers' had traditional intelligence approaches and parents and students were required to be informed about the theory. Moreover, in a study carried out by Erdem and Demirel (2005), it was drawn similar conclusions. The research was conducted with an aim to reveal the views of 72 teachers working at schools where 
multiple intelligences practices were implemented. The fact that students learned by entertaining in certain activities designed in line with the Theory of Multiple Intelligence and they were more eager to attend the classes is among the findings of the study. In addition, they highlighted that students attempted to put more effort into multiple intelligence practices. This may be interpreted that students who learn by entertaining are more engaged in lessons and put more effort to learn in such a process compared to the traditional education system.

The results of the study imply that informative activities regarding the Theory of Multiple Intelligence fail to achieve a goal. In light of teachers' statements, MoNE is required to offer in-service tranings which includes various activities and workshops regarding the use of multiple intelligences in teaching-learning processes, and teachers' voluntary participation should be ensured. In-service trainings for teachers towards multiple intelligences should be integrated with seminars arranged for parents. It is worth noting that the process should not only be followed by teachers, but parents are also required to be informed about it in order for multiple intelligence practices to be successfully carried out.

According to fourth and sixth-grade social studies teachers, social studies course books are insufficient for multiple intelligence activities, 'supportive books are needed, and the curriculum is highly intensive.' There was no teacher considering course books sufficient. The fact that teachers need supportive books, activities in the books are required to be contemporary and interesting, there is no teacher regarding books as sufficient, and other negative views have revealed that course books should be re-designed. This finding showed consistency with a study conducted by Koyuncuoğlu and Kaya (2000). In their study, it was found that the contents of course books are entailed to address all students by taking students' different intelligence domains into consideration. With this regard, teachers are recommended to explore their students' abilities, to pay attention to arranging activities in a way to appeal to different intelligence domains, and to use methods and techniques that are appropriate for the Theory of Multiple Intelligences.

According to Yenilmez and Bozkurt (2006), the Theory of Multiple Intelligence has brought about fundamental changes and advancements in education. However, it has been determined that teachers are not well-informed about how to carry out this theory in learning environments, and this situation is the key factor preventing above-mentioned developments. To handle these problems, applied workshops held by MoNE play a pivotal role. The projects and trainings planned by MoNE should be presented to teachers as interesting activities. The more those applications are regularly carried out, the more permanent the learning process becomes.

Besides, this study was conducted on behalf of fourth and sixth-grade students. Therefore, the study can also be carried out by making comparisons among different class levels or by investigating course books published by different publishers.

\section{Declaration of Conflicting Interests}

The author(s) declared no potential conflicts of interest with respect to the research, authorship, and/or publication of this article.

\section{Funding}

The author(s) received no financial support for the research, authorship, and/or publication of this article.

\section{Statements of publication ethics}

We hereby declare that the study has not unethical issues and that research and publication ethics have been observed carefully.

\section{Ethics Committee Approval Information}

This paper is adapted from the dissertation study carried out in Marmara University Institute of Educational Sciences Classroom Teaching Doctoral Program entitled 'Investigating Multiple Intelligence Applications in Learning Environments of the Course of Social Studies'.

\section{REFERENCES}

Acat, M.B. (2005). Applicability of the Multiple Intelligence Theory to the process of organizing and planning of learning and teaching. International Journal of Educational Reform, 14 (1), 4-72.

Başbay, A. (2005). Çoklu zekâ uygulamasına katılan öğretmenlerin ve öğrencilerin uygulama hakkındaki görüşleri üzerine nitel bir araştırma. Abant İzet Baysal Üniversitesi Eğitim Fakültesi Dergisi, 5(2), 189-206.

Bellanca, J. (1997). Active learning handbook for multiple intelligence classrooms. USA: IRI/Skylight Training and Publishing Inc.

Bümen, N. T. (2005). Okulda Çoklu Zekâ Kuramı: Ders planları, uygulamada karşılaşılan güçlükler ve Türkiye'deki çoklu zekâ okulu köy enstitüleriyle birlikte. 3. Baskı. Ankara: Pegem Yayınları.

Çağlayan E. \& Kıratlı, A. D. (2017). Resim bölümlerinde uygulanan eğitim programları hakkında öğretim elemanı görüşleri. Hacettepe Üniversitesi Eğitim Fakültesi Dergisi, 32(4), 780-793.

Demirel, Ö. (2000). Plandan uygulamaya öğretme sanatı. Ankara: PegemA Yayıncılık.

Demirel, Ö., Başbay, A. \& E. Erdem (2006). Eğitimde Çoklu Zekâ Kuram ve uygulamaları. Ankara: PegemA Yayıncılık.

Demircioğlu, İ. H. (2005). Tarih öğretiminde öğrenci merkezli yaklaşımlar. Ankara: Anı Yayıncılık. 
Doğan, Y. \& Alkış, S. (2007.). Sınıf öğretmeni adaylarının sosyal bilgiler derslerinde çoklu zekâ alanlarını kullanabilmelerine yönelik görüşleri. Uludağ Üniversitesi Eğitim Fakültesi Dergisi, 20(2), 327-339.

Erdem, E. \& Demirel, O. (2005). Çoklu Zekâ Kuramı'na ilişkin öğretmen görüşleri. XIV. Ulusal Eğitim Bilimleri Kongresi Bildirileri. Pamukkale Üniversitesi, Denizli.

Erman, A. (2003). Illköğretim 4. sınıf öğrencilerinin çoklu zekâ türlerindeki dağılım ve düzey ölçümlerinin müziksel zekâ düzeyleriyle karşılaştırmalı incelenmesi, Yayınlanmamış Yüksek Lisans Tezi, Gazi Üniversitesi, Eğitim Bilimleri Enstitüsü, Ankara.

Fleetham, M. (2014). Pocket pal: Multiple intelligences. London: Bloomsbury.

Gardner, H. (1993). Multiple intelligences: The theory in practise, Published by Basic Books, New York.

Gardner, H. (2019). Eğitilmemiş zihin. (çev. Merve Özenç Kasımoğlu). İstanbul: Alfa Yayınları.

İnan, C. \& Erkuş, S. (2016). İlkokulda çoklu zekâ kuramının uygulanabilirliğine ilişkin öğretmen görüşlerinin değerlendirilmesi. Eğitim ve Öğretim Araştırmaları Dergisi (Journal of Research in Education and Teaching), 5(4), 162-174.

Kabapınar, Y. (2012). Kuramdan uygulamaya hayat bilgisi ve sosyal bilgiler öğretimi (Genişletilmiş 3. baskı). Ankara: Pegem Akademi Yayınları.

Kaytancı, M. Ç. \& Dombaycı, M.A. (2020). Sorgulama topluluğunun felsefi ve kavramsal temelleri. Eğitim ve Öğretim Araştırmaları Dergisi, 9(2) 21-34.

Koyuncuoğlu, A. \& Kaya, Z. (2020). 6.sınıf fen bilimleri kitabının Çoklu Zekâ Kuramı'na göre incelenmesi. Ağrı ibrahim Çeçen Üniversitesi Sosyal Bilimler Enstitüsü Dergisi, 6(1), 19-45.

Kuran, K. (2005). Bir gelişim değişim süreci olarak eğitimde toplam kalite yönetimi ve aktif öğrenme ilişkisi. Çağdaş Eğitim Dergisi, 30(317), 1422.

Kuzgun, Y. \& Deryakulu, D. (2017). Eğitimde bireysel farklılıklar. Ankara: Nobel Yayın Dağıtım.

Merriam, S. B. (2018). Nitel araştırma desen ve uygulama için bir rehber. Ankara: Nobel Yayınevi.

Miles, M. B. \& Huberman, A. M. (1994). Quantitative data analysis: An expanded sourcebook.(2nd Ed.) Thousand Oaks. London. Sage publications.

MEB (2005). TTKB, Ilköğretim Sosyal Bilgiler Dersi 4-5. Sınıflar Öğretim Programı. Ankara: Devlet Kitapları.

Peterson, K. \& Kolb, D. A. (2018). How you learn is how you live: Nine ways of learning that can transform your life. Berrett-Koehler, San Francisco.

Saban, A. (2005). Çoklu Zekâ Teorisi ve eğitimi. 5. Baskı. Ankara: Nobel Yayınevi.

Temiz, N. (2007). Kimim-1? Öğretmenim, benim, beynim. Çoklu Zekâ Kuramı okulda ve sınıfta. Ankara: Nobel Yayınevi.

Tuğrul, B. \& Duran, E. (2003). Her çocuk başarılı olmak için bir şansa sahiptir: Zekânın çok boyutluluğu Çoklu Zekâ Kuramı. Hacettepe Üniversitesi Eğitim Fakültesi Dergisi, 24, 224-333.

Yenilmez, K. \& Bozkurt, E. (2006). Matematik eğitiminde Çoklu Zekâ Kuramı'na yönelik öğretmen düşünceleri. Mehmet Akif Ersoy Üniversitesi Eğitim Fakültesi Dergisi, 12, 90-103.

Yeşilbursa, E. G. (2006). Ilköğretim II. kademe sosyal bilgiler öğretmenlerinin Çoklu Zekâ Kuramı hakkındaki görüşleri (Yayımlanmamış yüksek lisans tezi), Gazi Üniversitesi Ĕgitim Bilimleri Enstitüsü, Ankara.

Yeşildere, S. (2003). Ilköğretim yedinci sınıf matematik dersi tamsayılar ünitesinde Çoklu Zekâ Teorisi tabanlı öğretimin öğrenci başarısına etkisi. (Yayınlanmış yüksek lisans tezi), Dokuz Eylül Üniversitesi Eğitim Bilimleri Enstitüsü, İzmir.

Yıldırım, A. \& Şimşek, H. (2011). Sosyal bilimlerde nitel araştırma yöntemleri. Ankara: Seçkin Yayınları. 